\title{
Analyzing Settlement Patterns of Bronze Age Sites at Bostan Abad, according Regional Archaeological Survey
}

\author{
Rahim Velayati ${ }^{1} \&$ Hamid Khanali ${ }^{2}$ \\ ${ }^{1}$ Faculty of Literature and Humanities, Tehran University, Tehran, Iran \\ ${ }^{2}$ Tarbiyat Modares University, Tehran, Iran \\ Correspondence: Rahim Velayati, Faculty of Literature and Humanities, Tehran University, Tehran, Iran. Tel: \\ 98-912-324-3721. E-mail: velayati@ut.ac.ir
}

Received: May 5, 2017

doi:10.5539/res.v9n3p36
Accepted: May 16, 2017

Online Published: June 20, 2017

\begin{abstract}
Archaeological surveys always present deep information about history of any given geographical area to archaeologists. Archaeologists have surveyed many Iranian regional areas, however, Bostan Abad, Eastern Azerbaijan, is among regions rarely archaeologically investigated. Present paper involves in analyzing settlement patterns and typology of Bronze Age of Bostan Abad according archaeological surveys at 1391 and 1392. Accordingly, some 36 Bronze Age sites identified, with two sites of Early Bronze Age, while the other remains date to Middle and Late Bronze Ages. It should be noted that archaeological survey based on surficial collected data, which make distinguishing Middle and Late Bronze Age a hard task. Conclusions signify from two aspects: from one hand, one should point to a geographical key role in locating settlements, on the other hand, typology of Potteries indicate inter regional communications, and strategic location of Bostan Abad. This zone is one of the most important hallways between Central Plateau of Iran and Northwest of Iran; however, regional investigations and connective role of the region and expansion of various cultures could reveal significant implications.
\end{abstract}

Keywords: Bronze Age, Kura—Araxes, Urmia pottery, Bostan Abad, pottery typology

\section{Introduction}

According to Archaeological excavation, a lot of area discovered in this region, but most of these investigations are in the west of the Urmia lake and the east part which is one of the important crossings, didn't received significant attention. The importance of choosing this area for study is because of its strategic location.

One could divide Bronze Age of northwestern Iran to three Early, Middle, and Late subdivisions (Talaei, 1385). The regional Early period is part of a more expanded culture that cover areas such as Anatolia, Levant, and Iran to northern Caucasia (Kushnareva, 1977), which known also with other names including Kura-Aras (after discovering numerous sites with the same period between two rivers of Kura and Aras; as Kuftin suggestion) (Kigguradze, 2000). Among the most remarkable material features of the culture across the regions that mentioned earlier and continued during later 1500-year period were residences with circular, square, and quasi-square plans and mud brick that coated with sedge. There were anthropomorphic or zoomorphic ovens, black and grey, or brown and redburnished handmade potteries; they masterly decorated in some cases by incised designs. Furthermore, one can refer to fine bone tools, bronze metal tools, figurines of horned animals, and obsidian tools (Kiguradze \& Sagona, 2003, p. 98). Subsistence of Kura-Aras societies mainly relied on farming and herdering with advances in irrigation and plowing, while they settled mountainous areas along with lowlands (Kushnareva, 1997, p. 183). By half 3rd millennium BC, Kura-Aras settlements suddenly abandoned, probably $2200 \mathrm{BC}$ as the end of Early Bronze Age (Özfirat, 2011, pp. 25-26). End of Early Bronze Age and beginning of Middle Bronze Age at southern Caucasia outline disappearing Kura-Aras culture and numerous communities that settled in rural areas. Among newly appeared features were changes in settlement patterns, as emergence of modern tribal patterns and bands that subsisted on herdering and pastoral lifestyles (Özfirat, 2001, p. 1).

The beginning of Middle Bronze Age and end of Early Bronze Age caused changes in settlement patterns of people, however, Kura-Aras culture disappeared and resident societies abandoned their villages, while new tribal 
elements emerged and subsistence was relying on herdering and pastoralism (Badalyan et al., 2003). Characteristic pottery of the period was painted polychrome vessel, which appeared at latter half of 2 nd millennium BC at Caucasia and Near East and endured to Iron Age I; when Local potters tended to local productions (Ağlarzade, 2009, p. 12); however, according to Meshaninov (1925, p. 38) vast expansion of painted polychrome vessels at Mesopotamia and Near East indicated cultural and economic relations among neighboring states. Present paper based on regional archaeological surveys that concluded to indistinguishable Bronze Age periods.

\subsection{Research Methods}

Basic conditions of settlements include natural and environmental sources in order to provide rudimentary human needs, from one hand, and secondary needs as sources for producing toolkits, suitable conditions to import and export goods, on the other hand. Therefore, investigating geological and climatic capabilities, and historic sources present significant implications; however, there have not been studies on settlement patterns of the period in Bostan Abad region that buffers between east and west of northwestern Iran; except archaeological survey of Stephen Krol and Kless that mentioned some sites that were belong to Bronze age. This study mainly aims to identify pre-historic and historic areas, and not a reference to Islamic sites (Kless \& Krol, 1992, pp. 4-5). Accordingly, it is highly significant defining regional settling characteristics. Here, there is an involvement in analyzing settlement pattern of Bostan Abad Bronze Age using Arc GIS and environmental studies. The patterns engaged in defining factors governing on settlement location, considering water resources, altitude, humidity, slope, land function, and area. Recovered data systematically collected (Velaiati, 1392; Velaiati, 1393).

\subsection{Geographical Location of Investigated Region}

Bostan Abad is located at $45 \mathrm{Km}$ of Tabriz, Eastern Azerbaijan, at $46^{\circ} 50^{\prime}$ longitude, $37^{\circ} 51^{\prime}$ latitude, and $1740 \mathrm{~m}$ altitude, at Mianeh-Tabriz road. Bostan Abad consists of nine rural districts, whereas Eastern and western Ujan, Sahand Abad, at 1392 (second season), and two southern and central Mehranrud rural areas at 1393 (third season) (Figures 1,2).

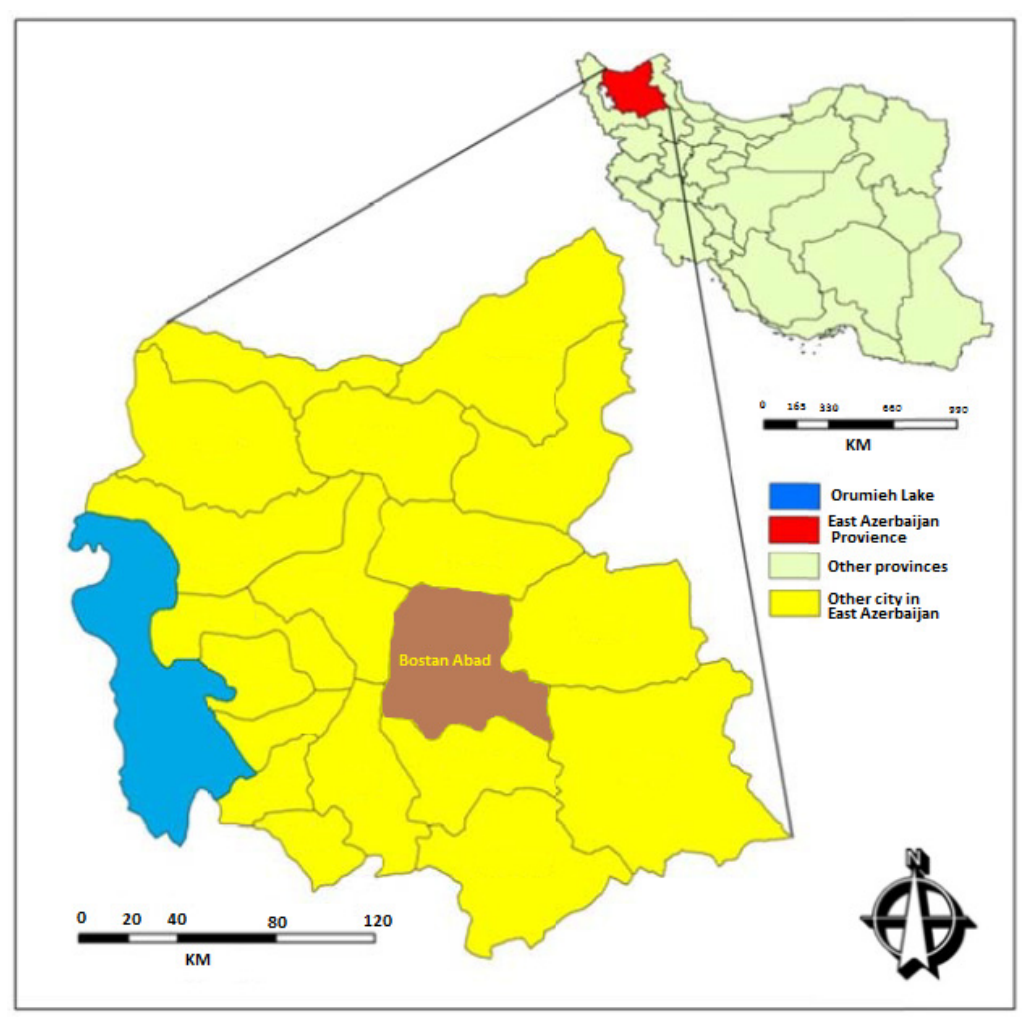

Figure 1. Geographical location of Eastern Azerbaijan province 


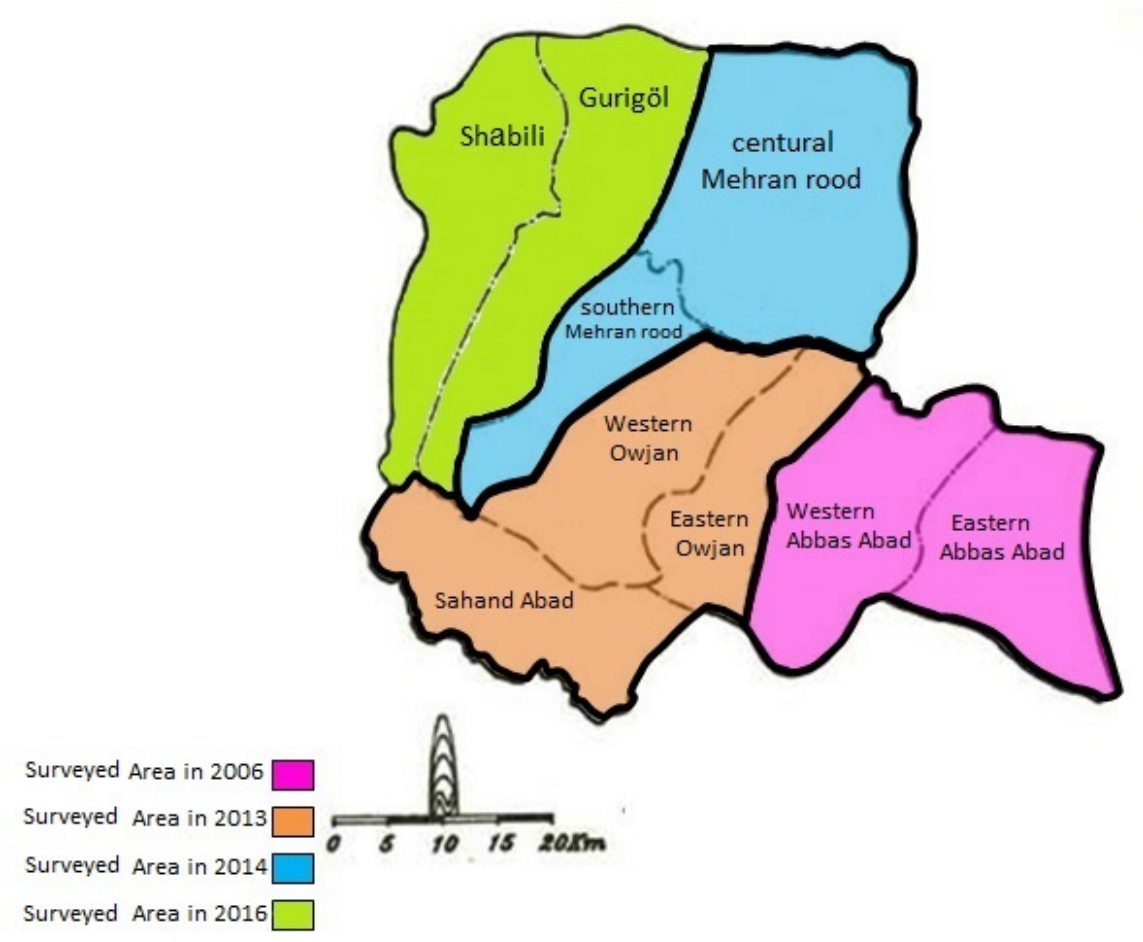

Figure 2. Archaeological surveyed area at 2006-2016, Bostan Abad

\section{Data Description}

\subsection{Identified Sites and Recovered Potteries of Early Bronze Age}

Rural districts of central and southern Mehranrud and Sahand Abad archaeologically surveyed, which concluded to identifying and documenting more than 140 archaeological sites (Velaiati, 1393, pp. 12-13). According studies, more than 36 sites dated back to Bronze Age with two Darre Si (Bos-93-57) and UzMazar (Bos-93-65) (Figure 3) as Early Bronze Age; here, potteries documented as Kura-Aras. There were six sites of Bos-93-129, Bos-92-24, Bos-92-186, Bos-92-181, Bos-93-182, and Bos-93-99 with later evidence, weakly assigned to Khabur phase. The sites indicate evidences of Late Bronze Age (Madani, 1394). Among collected potsherds of Early Bronze Age from the sites, there were two pieces of rims one was comparable to 6 and 7 forms and form 21 of type F, while the other compared to form 73, 141, 192, according to Sagona Classification (Sagona 1984). The two pieces were remains of jars (Figure 4, Table 2).

Table 1. Identified Early Bronze sites

\begin{tabular}{cccccc}
\hline No. & site & Reg. no. & longitude & latitude & altitude \\
\hline 1 & UzMazar & Bos 92.186 & 46.46 .54 & 37.46 .53 & $1890 \mathrm{~m}$ \\
2 & Darre $\mathrm{Si}$ & Bos 93.57 & 46.42 .34 & 37.51 .36 & $1920 \mathrm{~m}$ \\
\hline
\end{tabular}



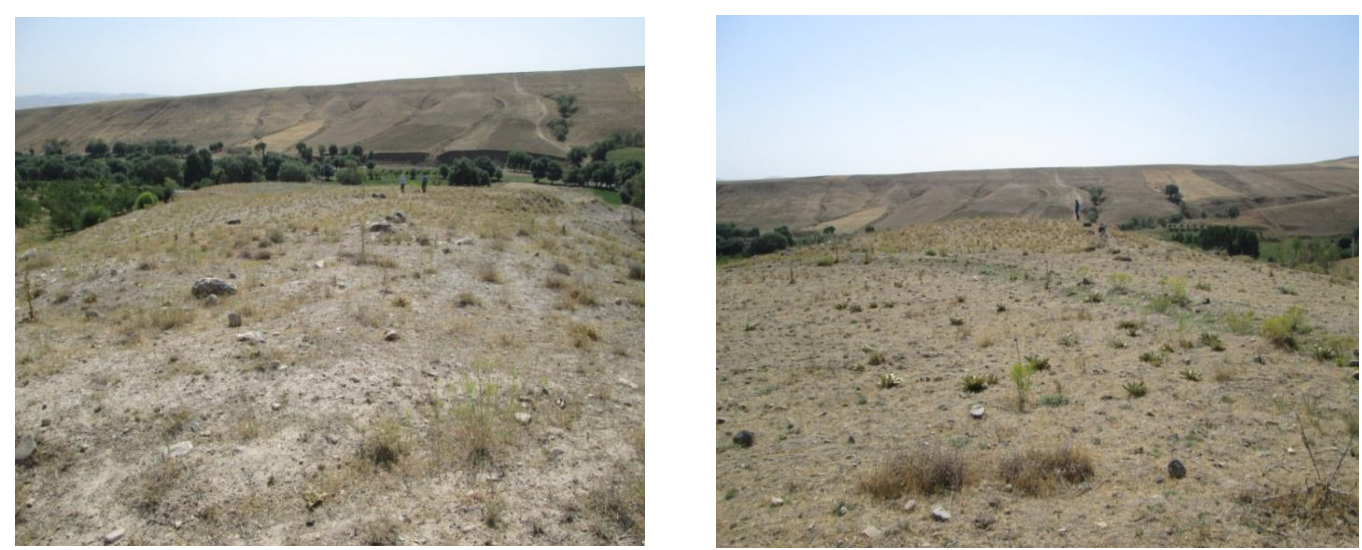

Figure 3. View of UzMazar site

Table 2. Pottery from Early Bronze Age, Bostan Abad

\begin{tabular}{|c|c|c|c|c|c|c|c|c|c|c|c|c|}
\hline No. & site & Reg. no. & type & form & structure & temper & Outer color & Inner color & coat & Slip & note & Comparison \\
\hline $53-5$ & $\begin{array}{c}\text { Darr } \\
\text { esi }\end{array}$ & 4 & $\begin{array}{l}\text { Rim, } \\
\text { Body }\end{array}$ & Jar & Handmade & $\begin{array}{l}\text { Minera } \\
1 \text {, sand }\end{array}$ & Black & Black & Black & $\begin{array}{c}\text { wet hand and } \\
\text { burnished }\end{array}$ & $\begin{array}{c}\text { Early } \\
\text { bronze Age }\end{array}$ & $\begin{array}{c}\text { Burney } \\
\text { 1962: plate XIIII: } 4\end{array}$ \\
\hline $45-5$ & $\begin{array}{l}\text { UzM } \\
\text { azar }\end{array}$ & 7 & rim & $\begin{array}{l}\text { Open } \\
\text { jar }\end{array}$ & Handmade & $\begin{array}{c}\text { Minera } \\
1\end{array}$ & red & red & red & ----- & $\begin{array}{l}\text { Bronze } \\
\text { Age }\end{array}$ & $\begin{array}{l}\text { Sagona } 2004 \text { figure } \\
17: 4 \\
\text { Edwards } 1983 \text { figure } \\
81: 5\end{array}$ \\
\hline
\end{tabular}

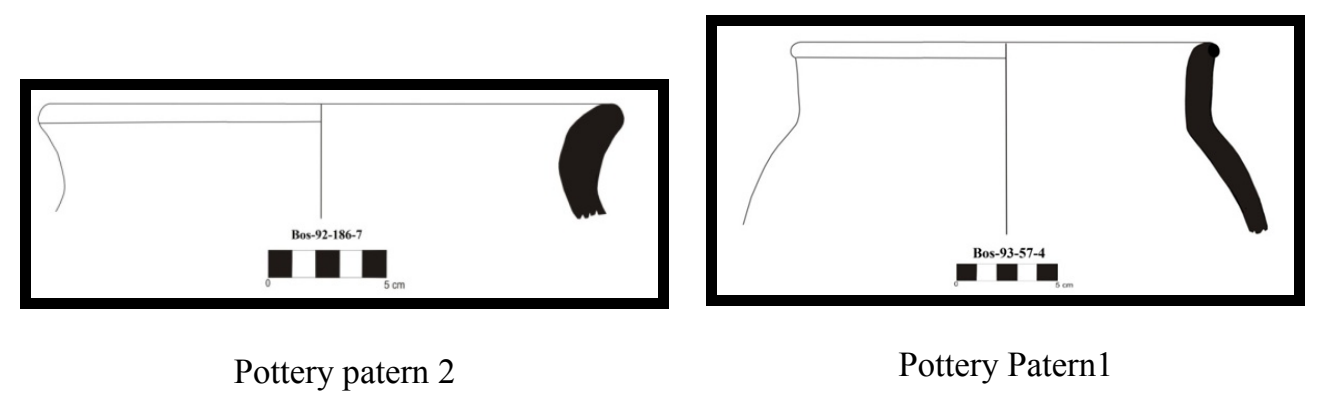

Figure 4. Early Bronze Age potsherds, Bostan Abad

\subsection{Middle and Late Bronze Age Sites}

There were numerous Middle and Late Bronze Age sites during 1st half of 2nd millennium, among them were 34 sites that culturally compared to a painted pottery tradition so called as Urmia Type (Table 3).

Table 3. Bronze Age sites

\begin{tabular}{cccccc}
\hline No. & Site & Reg. no. & longitude & latitude & Altitude (m) \\
\hline 1 & Tyb Bolaghi, Jafr village & Bos 92.5 & $46,47,06$ & $37-15-48$ & 1850 \\
2 & Teppe Ismail Qabi Aqcheh Kahal & Bos 92.9 & $46,50,38$ & $37-40-08$ & 1940 \\
3 & Kalleh Pain, Bash bolagh village & Bos 92.15 & $46,49,09$ & $37-40-12$ & 1974 \\
4 & Yurt yeri & Bos92.17 & $46,48,29$ & $37-40-23$ & 2005 \\
5 & Kulyerinoshahr & Bos92.24 & $46,48,18$ & $37-42-30$ & 2039 \\
6 & KulyeriGulujeh & Bos92.43 & $46,46,28$ & $37-41-33$ & 2028 \\
\hline
\end{tabular}




\begin{tabular}{|c|c|c|c|c|c|}
\hline 7 & Sakhsi Yeri Ghazanghuzun & Bos92.45 & $46,51,30$ & $37-43-97$ & 2002 \\
\hline 8 & Ghazi Kul, TazehK and village & Bos92.51 & $46,51,39$ & $37-44-14$ & 1911 \\
\hline 9 & Posht-i-Kuh-i-Qasim & Bos92.57 & 41,8900 UTM & S38 67-25-86 & 2429 \\
\hline 10 & KharmanLar & Bos 92.58 & $46,56,11$ & $37-48-43$ & 2021 \\
\hline 11 & PariJahan Ulan & Bos92.66 & $45,55,23$ & $37-47-14$ & 1931 \\
\hline 12 & Kaleh Lar Ein al-Din & Bos92.69 & $46,55,03$ & $37-47-04$ & 1923 \\
\hline 13 & Baigush Kaleh Li & Bos92.95 & $46,41,24$ & $37-42-45$ & 2137 \\
\hline 14 & Kul Tepe Amr Allah & Bos92.96 & $46,41,21$ & $37-42-35$ & $?$ \\
\hline 15 & Amr Allah & Bos92.99 & $46,41,15$ & $37-42-47$ & $?$ \\
\hline 16 & Ashari Chai & Bos92.115 & $46,44,17$ & $37-45-52$ & 1986 \\
\hline 17 & North of Bagh-i-Bineh Kahal & Bos92.123 & $46,47,50$ & $37-45-46$ & 1935 \\
\hline 18 & Dashli Qaleh & Bos 92.129 & $46,48,14$ & $37-45-02$ & --- \\
\hline 19 & Guza' & Bos 92.164 & $46,48,14$ & $37-45-02$ & --- \\
\hline 20 & East of Khachik village & Bos92.171 & $46,40,43$ & $37-37-14$ & 2058 \\
\hline 21 & Rajab Ali Tepe & Bos 92.181 & $46,48,59$ & $37-47-31$ & 1801 \\
\hline 22 & Gamish Ulan & Bos92.182 & $46-47-12$ & $37-46-02$ & 1937 \\
\hline 23 & TilTakhti & Bos93.1 & $46-36-53$ & $37-42-53$ & 2315 \\
\hline 24 & Zaman Yaeri 1 & Bos93.19 & $46-41-40$ & $37-48-18$ & 2049 \\
\hline 25 & AqDarre Tepe & Bos93.27 & $46-40-41$ & $37-48-33$ & 1986 \\
\hline 26 & Qaleh Juq Diznab Piri & Bos93.31 & $46-42-34$ & $37-50-12$ & 1929 \\
\hline 27 & Kat Darre Si 3 & Bos93.57 & $46-42-34$ & $37-51-36$ & 1920 \\
\hline 28 & Qizil Qaleh Halan Mansion & Bos93.63 & $46-48-23$ & $37-49-51$ & 1790 \\
\hline 29 & SisanYaeri & Bos93.65 & $46-49-57$ & $37-49-59$ & 1794 \\
\hline 30 & Kand Dali Kilns & Bos93.79 & $46-01-27$ & $37-0-20$ & 1696 \\
\hline 31 & Alladim & Bos93.92 & $46-54-59$ & $37-57-53$ & 1643 \\
\hline 32 & Kand Yaeri Dash Khan & Bos93.99 & $46-54-35$ & $37-52-34$ & 1903 \\
\hline 33 & Kat Yaeri Tarkampur & Bos93.110 & $46-51-17$ & $37-58-12$ & 1775 \\
\hline 34 & Chador Yaeri & Bos93.129 & $46-50-36$ & $37-52-48$ & 1803 \\
\hline
\end{tabular}

KarvansaraYaeri (Bos 93.123) is one of the most significant sites of Late Bronze Age that locates next to Janbahan village and covers $50 \times 90 \mathrm{~m}^{2}$ area (Figure 5), where there were recovered few characteristic polychrome potsherds of Urmia (Figure 6, Table 4). 

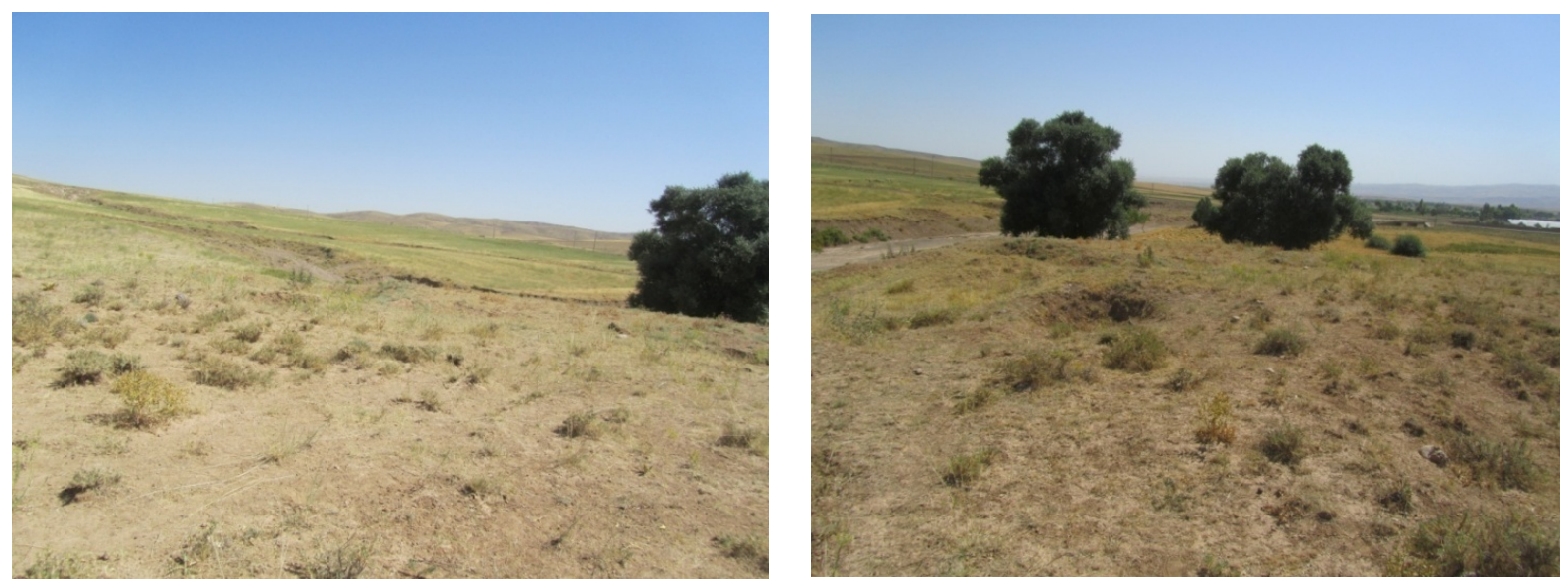

Figure 5. Close view of Karvansara Yaeri (Velaiati, 1393, p. 147)

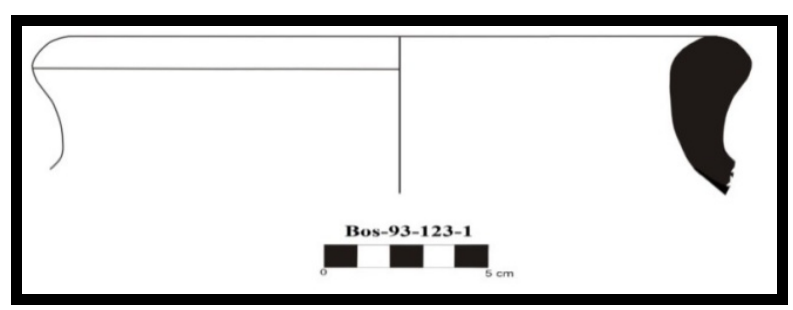

Pottery Pattern 1

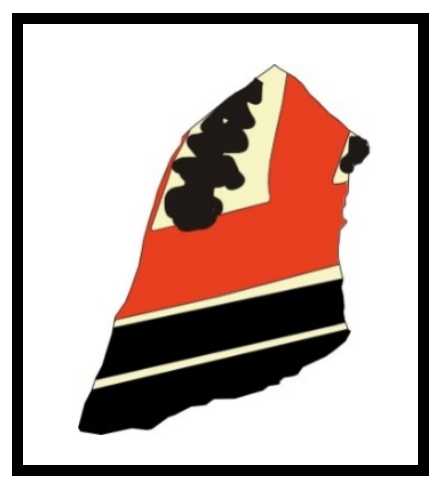

Pottery Pattern 3

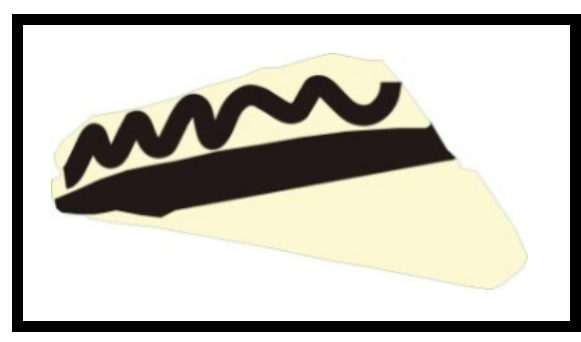

Pottery Pattern 2

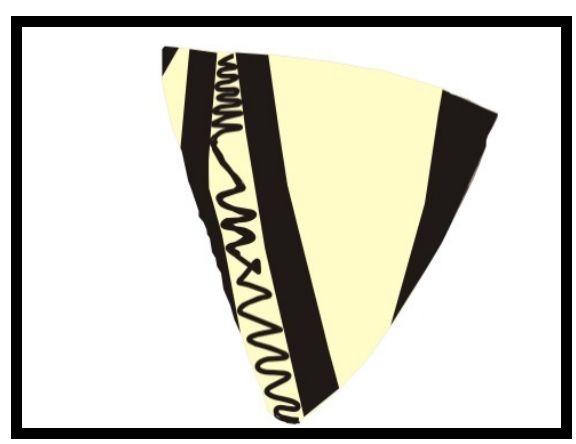

Pottery Pattern 4

Figure 6. Urmia painted potsherd, recovered from Karvansara Yaeri

Table 4. Features of Urmia painted potsherd, recovered from Karvansara Yaeri

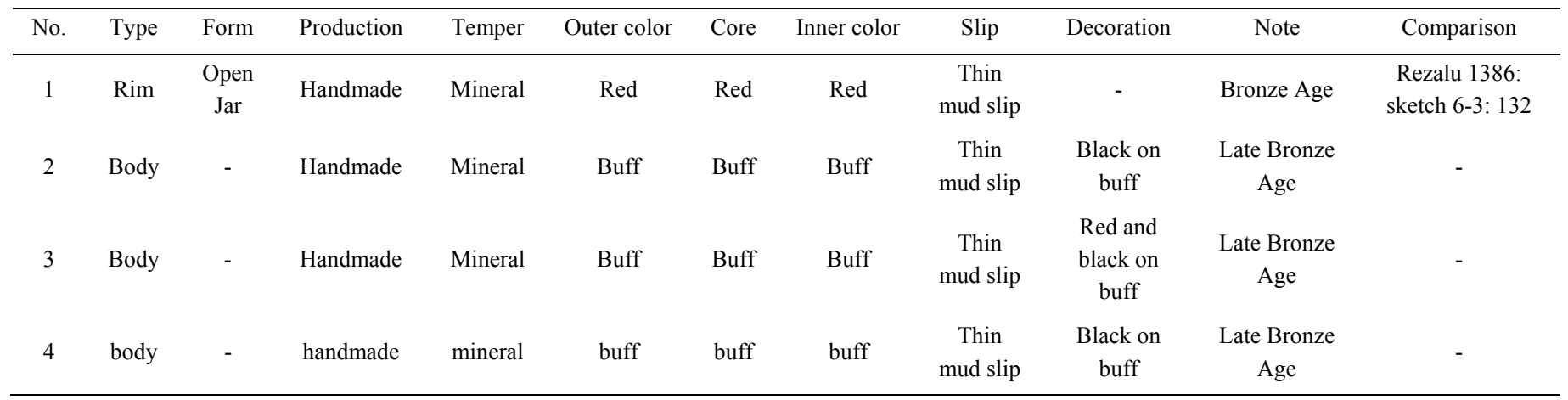




\subsection{Typology of Recovered Middle and Late Potsherds}

Khabur and Urmia are two major types of Middle and Late Bronze clay vessels type. Khabur type of pottery has not been found from the region yet, however, in the absence of characteristic pieces, there are some plain fragments that highly unlikely identify as Khabur type. It is probably for method of collecting samples, although, it appears local features superimposed pottery traditions that caused some stratigraphic problems in eastern areas of western and northwestern regions. Urmia type of Pottery is the most significant identified pottery type of Middle and Late Bronze Age of region, which Edwards described, for first time, after excavation of VIb layer of Haftvan, however, he knows the term as Stronach's suggestion (Edwards, 1983, p. 121; 1981, p. 115). Urmia vessels distributed through northwest of Iran, southern Caucasia, and Eastern Anatolia (Mirzaei, 2014, pp. 11-15). Despite of common features, Urmia pottery type indicates regional differences that limited to Urmia Lake basin, southern foothills of Caucasian mountains, northeastern Anatolia, and Moghan alluvial plain (Belli \& Bahşaliyev, 2001, p. 51). Few scholars including Kushnareva (1997, p. 84), Belli and Bahşaliyev (2001, p. 51), and Özfirat (2001, p. 17) regionally classified the type, considering dominant regional decorations as following: 1) Terialty-Kirovakan, 2) Tazkand (Karmir-Bard), 3) Sevan-Uzerlik Tepe, 4) Van-Urmia, 5) Sagz Abad (Mirzaei, 2014, p. 138). Regarding chronology of Urmia vessels at Middle and Late Bronze Age, latest classification presents as: Early Bronze Age 2200-2000 BC, Middle Bronze Age VIb 2000-1450 BC, and Late Bronze Age 1500-1350 BC (Mirzaei, 2014, p. 266, Table 1). The vessels of the subdivision indicate black designs on buff, brown/light brown; with cream/buff slips on upper parts of vessels of Late Bronze Age that made background for brown/light brown or black designs (Özfirat, 2001, pp. 24-25). They are burnished potteries with fine sand temper and completely kilned (Mirzaei, 2014, p. 141). Designs include geometrical motifs of wave like strips, series of butterflies, rhombs, squares, and triangles, while there are various fillings including parallel straight or wavelike and dotted strips (Ibid., p. 16). Among recent researches on Urmia pottery tradition are excavations at cemetery of Khanghah Gilvan (Rezalu, 1385), Kul Tepe Jolfa (Abedi, Omrani, \& Eskandari, 2012) and Ghayaligh Tulesh Khalkhal (Khanali, 1393).

Here, the authors typify recovered potsherds as bowls, plates, jars, and beakers classes. Bowls subdivided to two groups of bowls with outwardly folded rim (Figure 7), and bowls with inwardly folded rim (Figure 8). Totally, there have been identified 4 types of plates (Figure 9). Jars have numerous variations that generally subdivided to necked (Figure 10) and without neck (Figure 11) groups. There has been recovered only one beaker (Figure 12). There have been twenty four bowls of recovered Late Bronze vessels which comprise $37 \%$ of the collection. Bowls with outwardly folded rims were 10 that consisted $15 \%$ of the collection, whereas bowls with inwardly folded rims were 14 in number and comprised $22 \%$ of the collection. Plates were 8 in number that consisted around $12.5 \%$ of the collection. Necked jars were 19 pieces that consisted $29.5 \%$ of the collection, while Jars without neck were 12 as $19 \%$ of the statistics. Beakers consisted about $2 \%$ of the collection. Chromatically, the collection consist of $9 \%$ orange, $40 \%$ brown, $31.5 \%$ red, $12.5 \%$ buff, and $7 \%$ grey/black potteries. They are $72 \%$ handmade, and $28 \%$ wheelmade. 


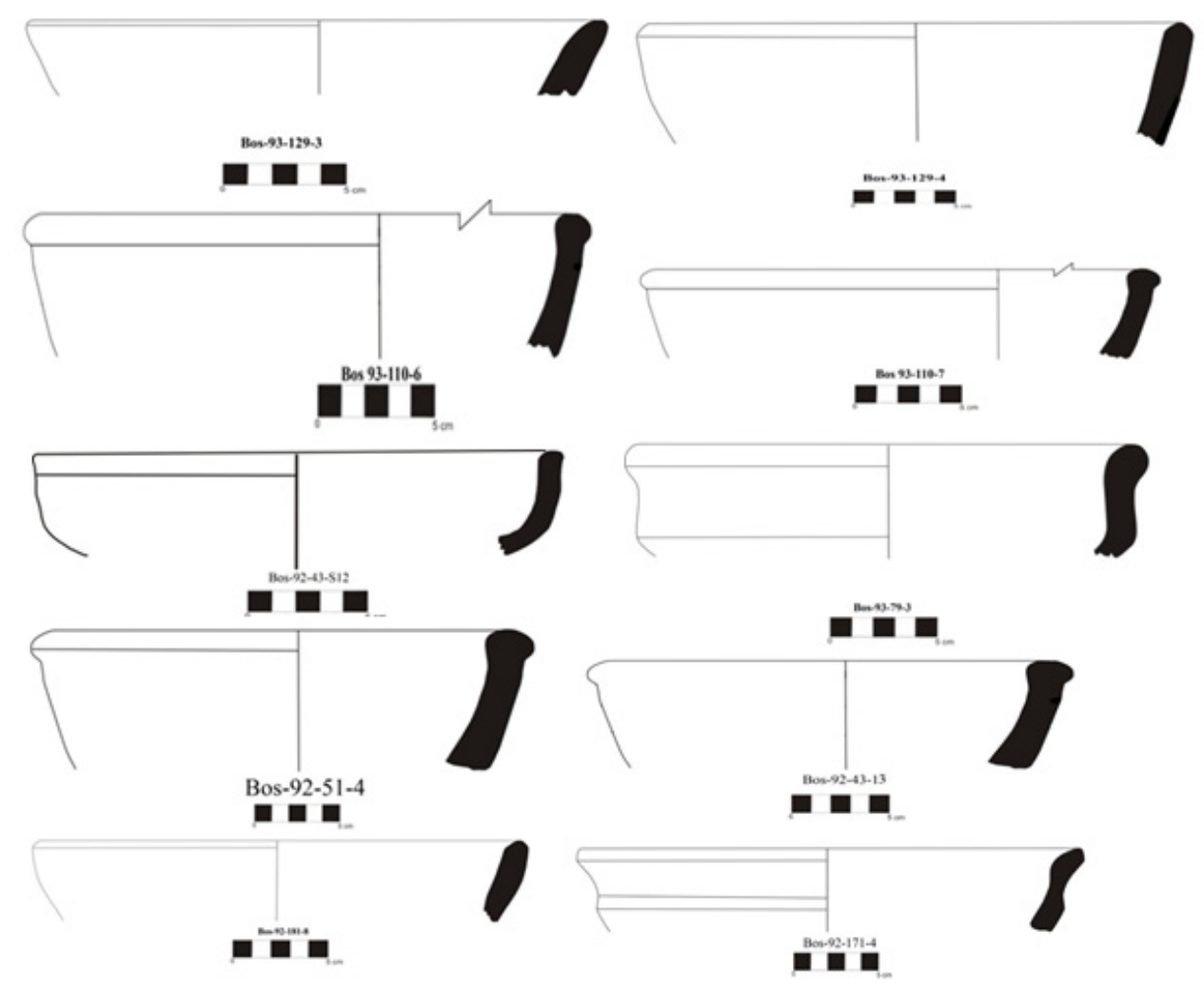

Figure 7. Bowls with outwardly folded rims

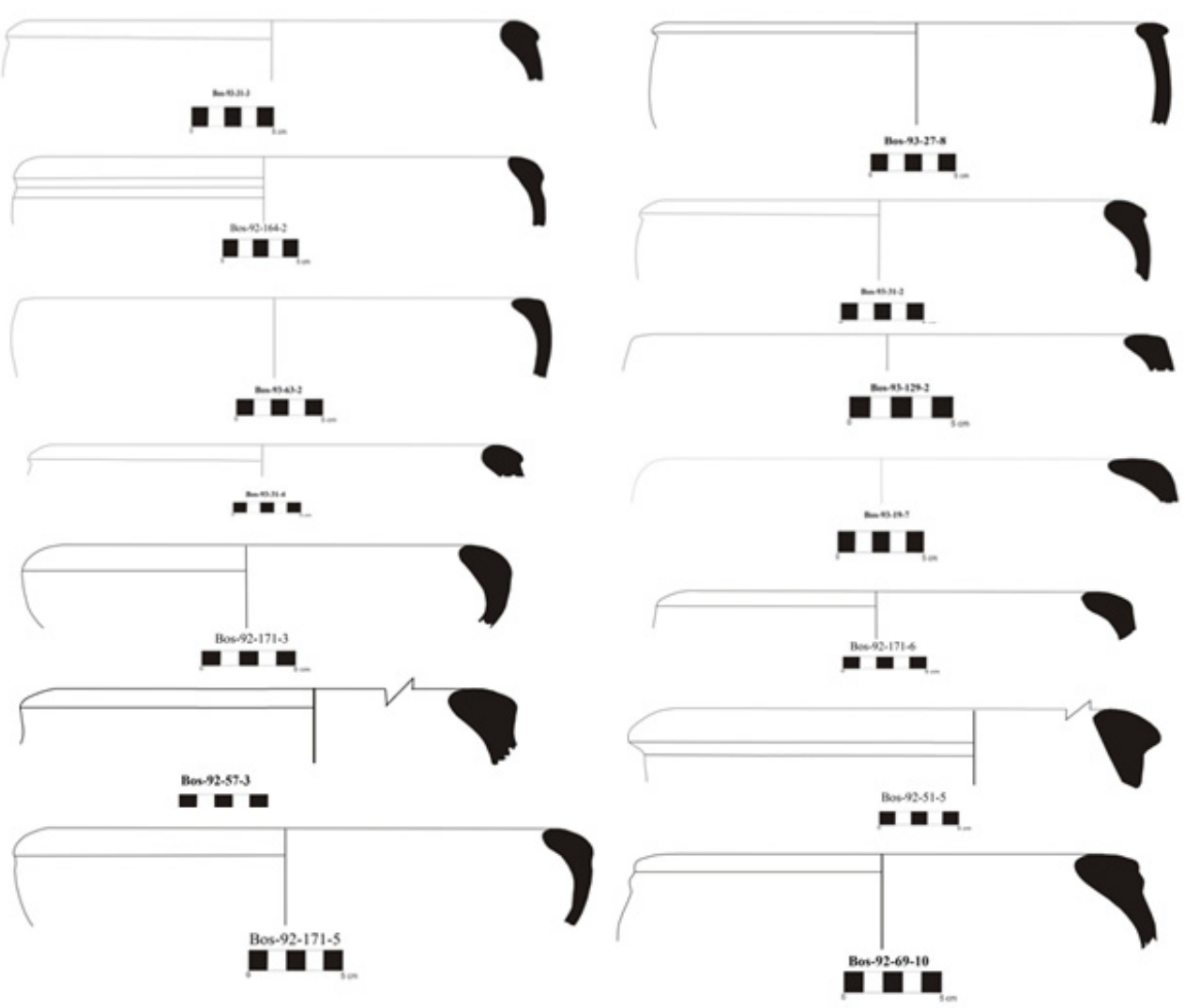

Figure 8. Bowls with inwardly folded rims 


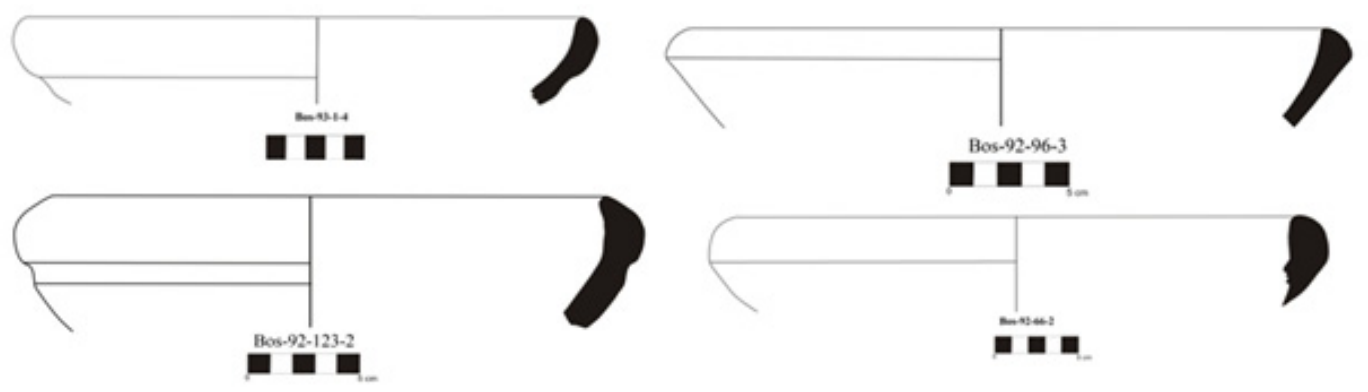

Figure 9. Recovered plates after regional survey

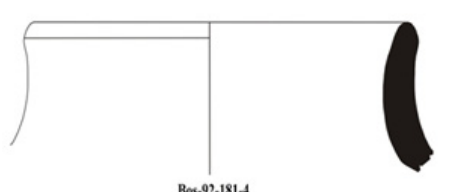

Bos-92-181-4

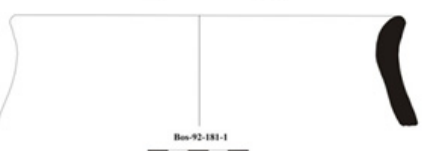

$\mathbf{\square}^{\operatorname{man} n \cdot \sin -1} \mathbf{\square}$

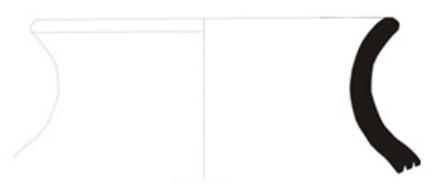

aneses
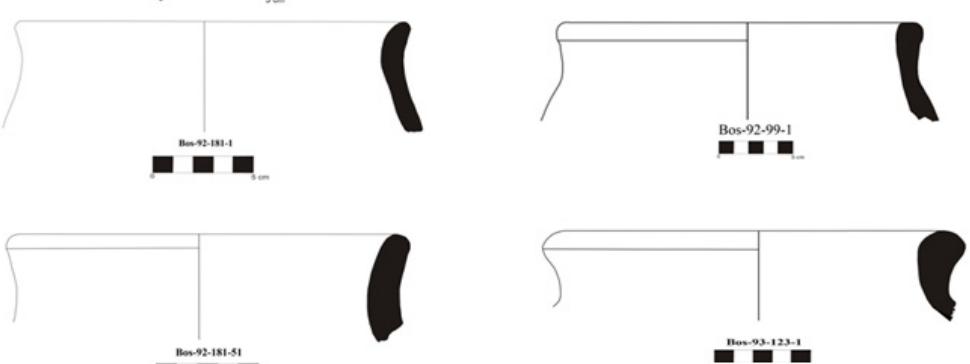

口

$\stackrel{n+93.123-1}{\operatorname{man}}$
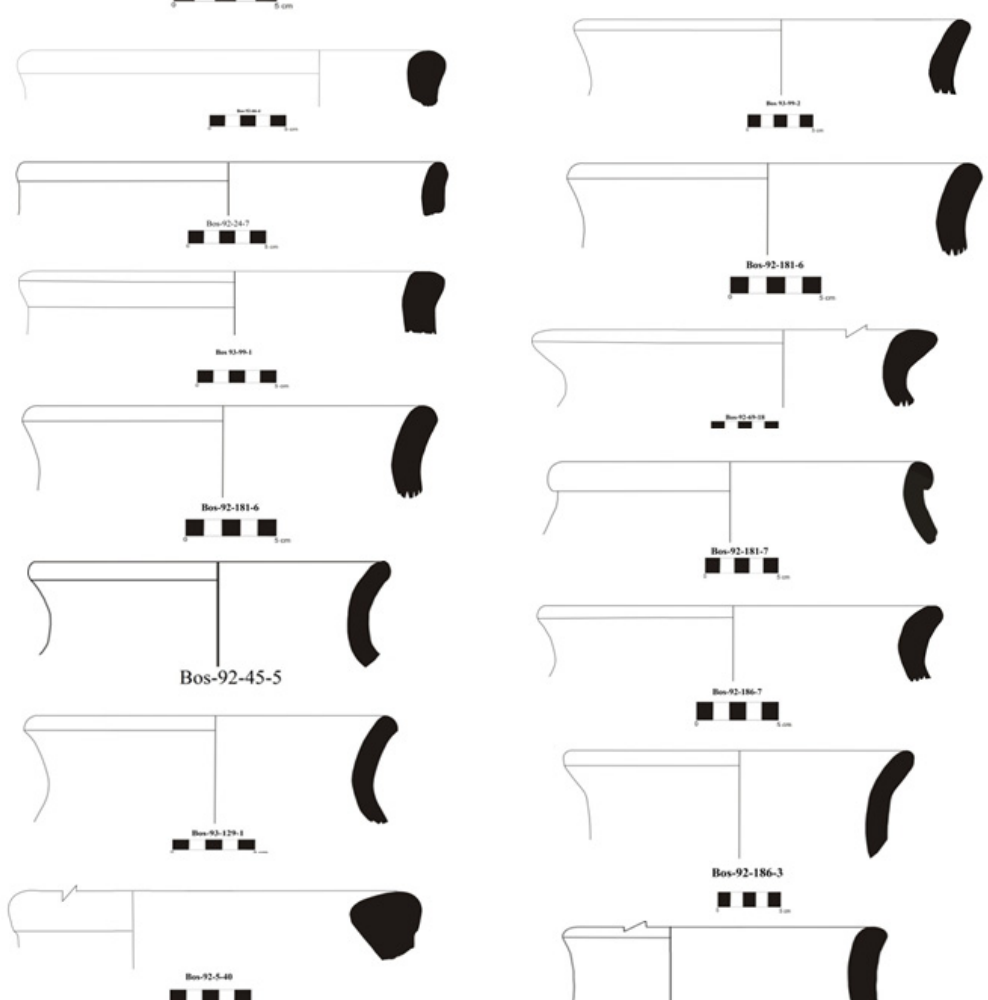

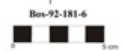

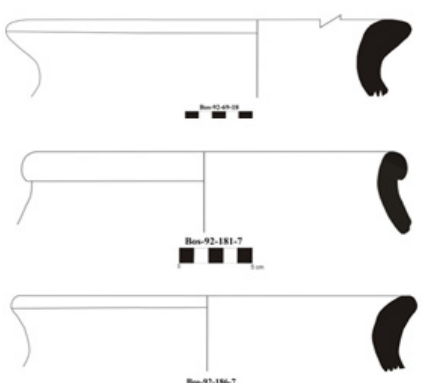

ana

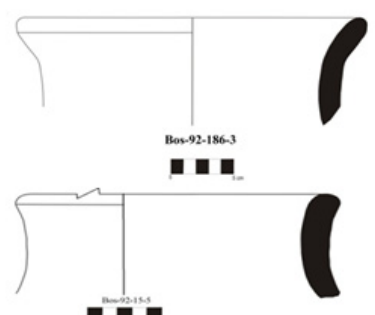

Figure 10. Recovered necked jars from the region 


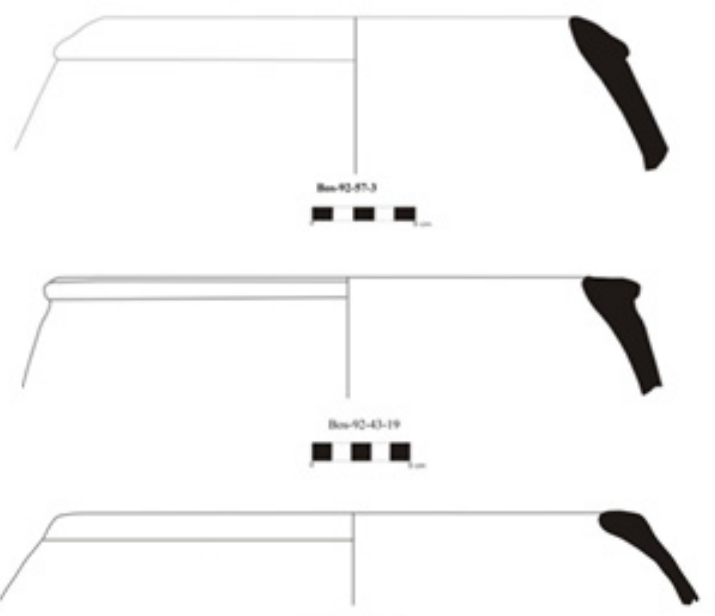

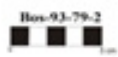
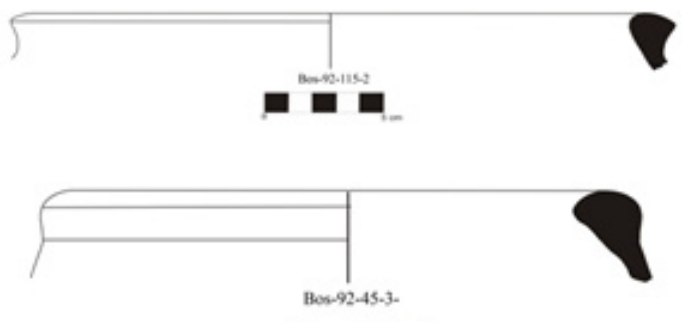

口

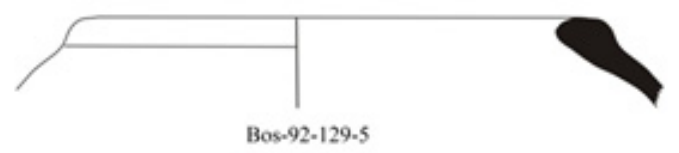

口曰

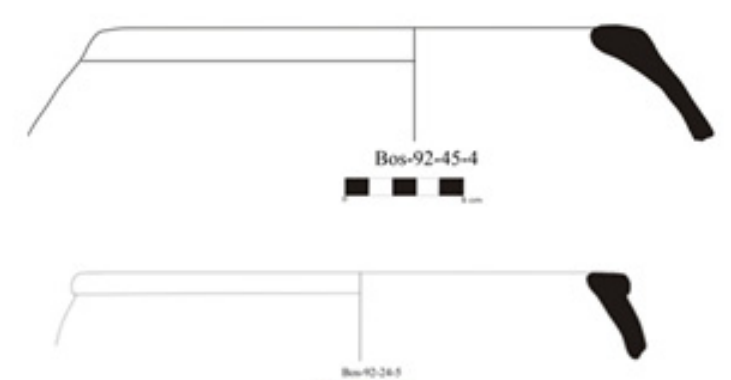

물.

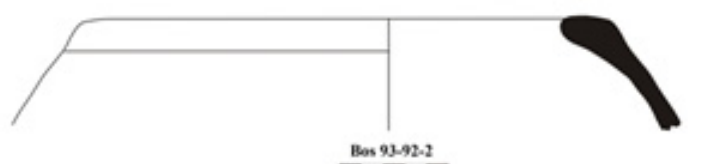

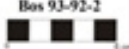
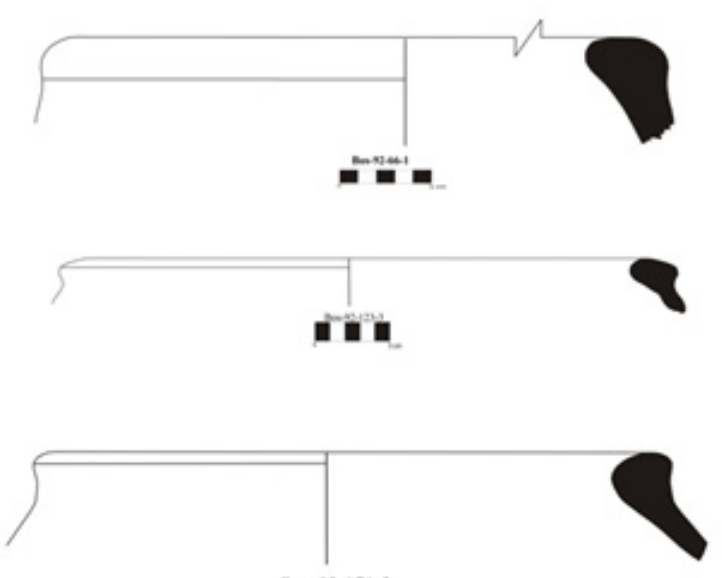

Bos-92-171-2

Figure 11. Recovered necked jars from the region

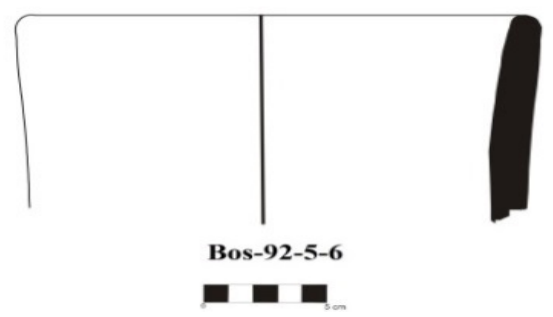

Figure 12. Recovered beaker from the region

\section{Analysis of Locating and Settlement Expansion}

\subsection{Distribution Pattern of Bronze Age Sites, Considering Water Resources}

Certainly, one could say water sources played significant role in formation of human settlements. The most important regional water source is Ujanchai River, of main branches of Saravshahr River. The other modern water sources include Ayqarchai, Upper and Lower Ujanchai, Sabrichai, Pirlichai, Asbabadchai, and few springs 
and Qantas. They originate from Sahand Mountains and flow to Bostan Abad Plain. According distances from river, sites classified to groups of 1) 0-500 m, 2) 500-1000 m, 3) 1500-2000 m, 4) 1500-2000 m, and 5) more than $2000 \mathrm{~m}$. As $47 \%$ of sites, distances of 17 sites were less than 500 meters, which consist of 4 sites of Early Bronze Age to early 2nd millennium, while the rest date to later periods until Early Iron Age. There are 5 sites as second group that comprise $14 \%$ of sites as 1 Early Bronze to early 2nd millennium and 4 Late Bronze sites. 3 sites, as $8 \%$ of the collection consist group three with 1 site of Early Bronze Age to early 2nd millennium. There were registered 6 sites within group 4 that comprise $17 \%$ of the collection while completely date to Late Bronze Age. The fifth group includes 5 sites (14\%) with more than $2000 \mathrm{~m}$ that date to Early Bronze Age, 2 sites, and late 3rd millennium to Early Iron Age, 3 sites (Table 5, Figures 13, 14).

Table 5. Distance of sites from water resources

\begin{tabular}{ccccc}
\hline $\begin{array}{c}\text { Distance from water } \\
\text { sources (m) }\end{array}$ & $\begin{array}{c}\text { Number } \\
\text { of sites }\end{array}$ & $\begin{array}{c}\text { Early Bronze to late 3rd } \\
\text { millennium }\end{array}$ & $\begin{array}{c}\text { late 3rd millennium to } \\
\text { Early Iron Age }\end{array}$ & percent \\
\hline $0-500$ & 17 & 4 & 13 & 47 \\
$500-1000$ & 5 & 1 & 4 & 14 \\
$1000-1500$ & 3 & 1 & 2 & 8 \\
$1500-2000$ & 6 & 0 & 6 & 17 \\
$>2000$ & 5 & 2 & 28 & 14 \\
total & 36 & 8 & & 100 \\
\hline
\end{tabular}

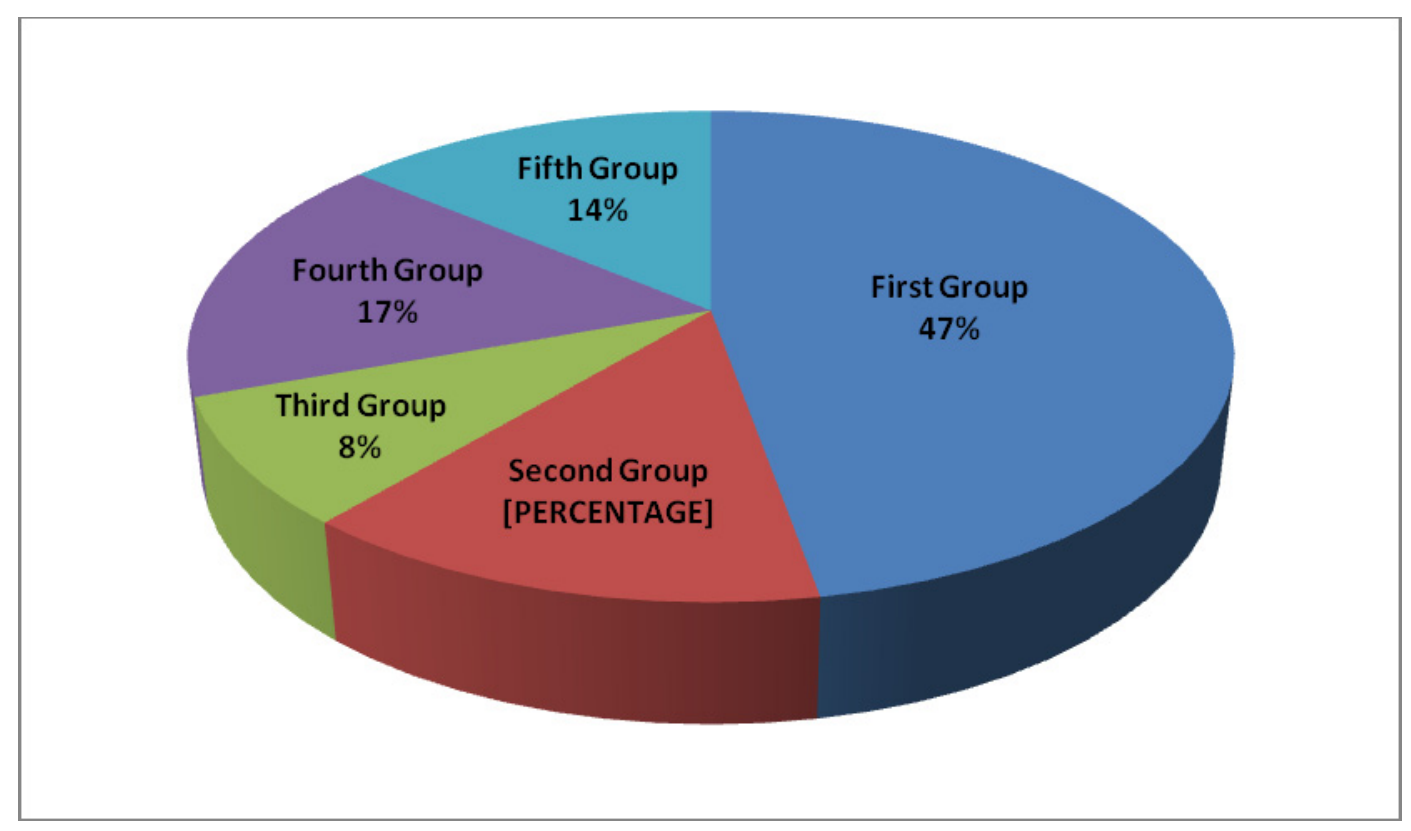

Figure 13. Abundance of sites according to water resources 


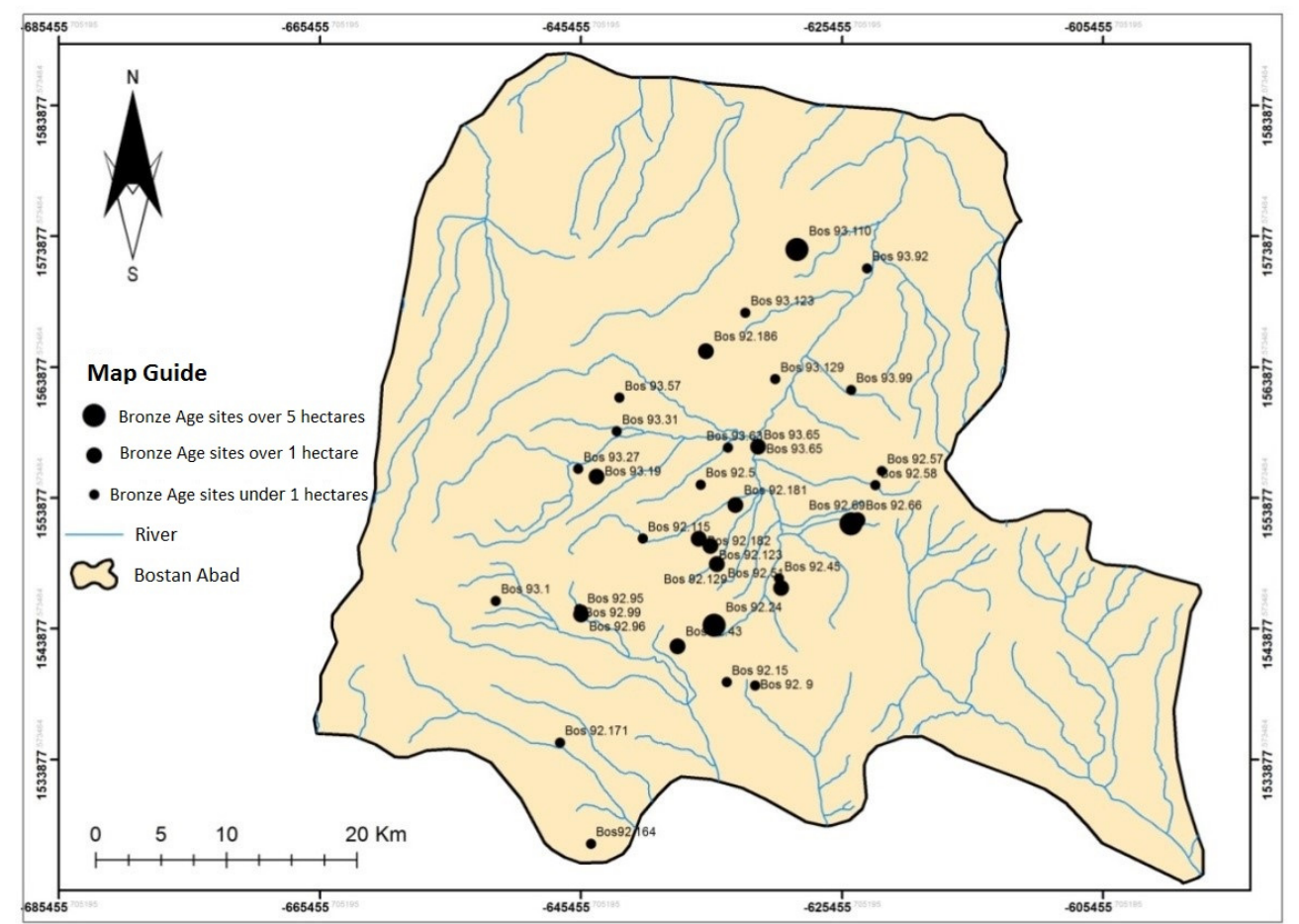

Figure14. Bronze Age sites of Bostan Abad, considering rivers

\subsection{Distributing Patterns of Bronze Age Sites according to Altitude}

Accordingly, Bostan Abad consists of five groups including 1) 1400-1700 m, 2) 1700-2000, 3) 2000-2500 m, 4) $2500-3000 \mathrm{~m}$, and 5) 3000-4000 m. There is 1 site of Late Bronze Age at 1400-1700 m. There are 23 sites at 1700 to $2000 \mathrm{~m} ; 12$ sites position at 2000 to $2500 \mathrm{~m}$, while there have not been any sites of group 2 (Figure 15).

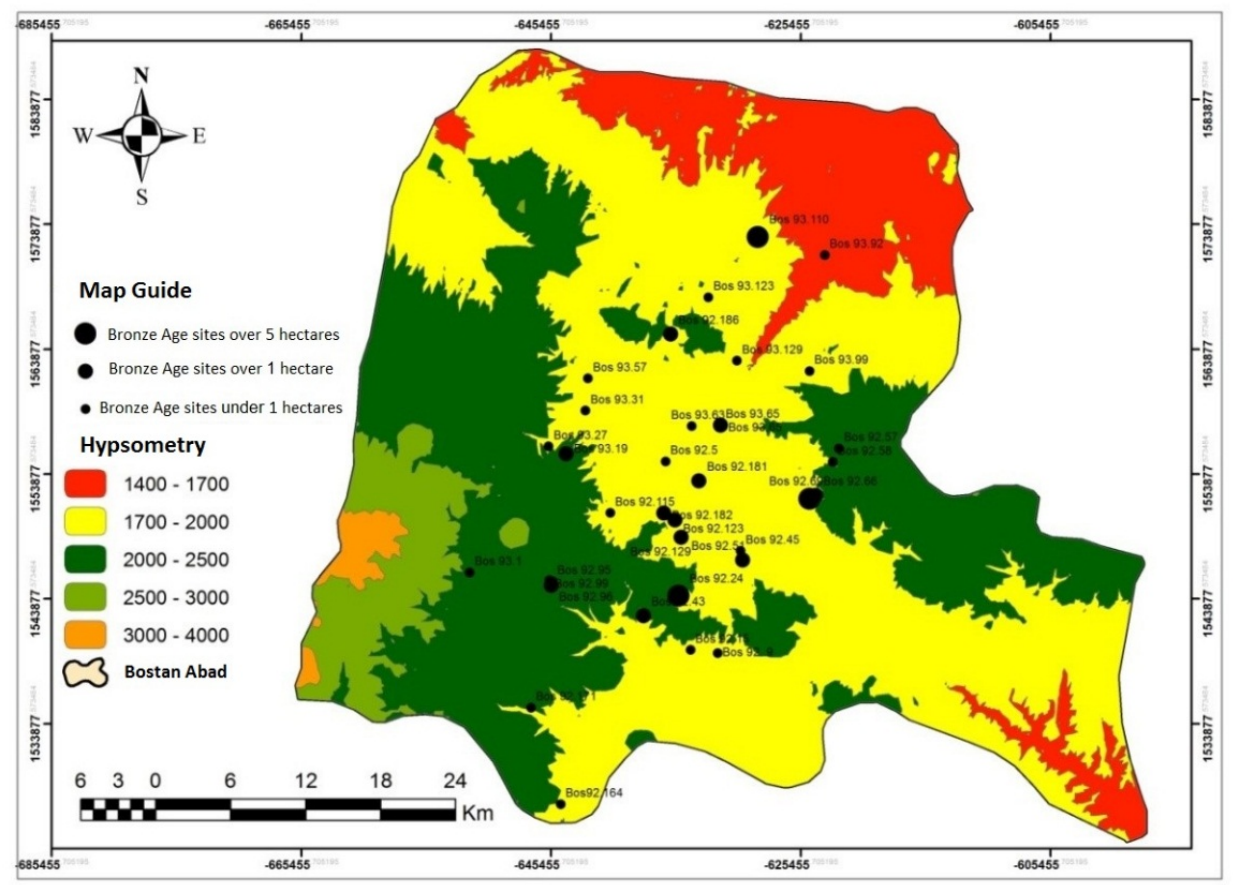

Figures 15. Bronze Age sites of Bostan Abad, according altitude 


\subsection{Distributing Pattern of Bronze Age Sites according to Humidity}

Accordingly, Bostan Abad region divides to 4 groups of wet, semi wet, middle semi-arid, and intense semi-arid. Following the categorization, 2 sites locate at semi-arid region and 34 sites at wet region, while the first two date to Late Bronze Age and 8 sites of 34 remains date to Early Bronze Age to late 3rd millennium BC (Figure 16).

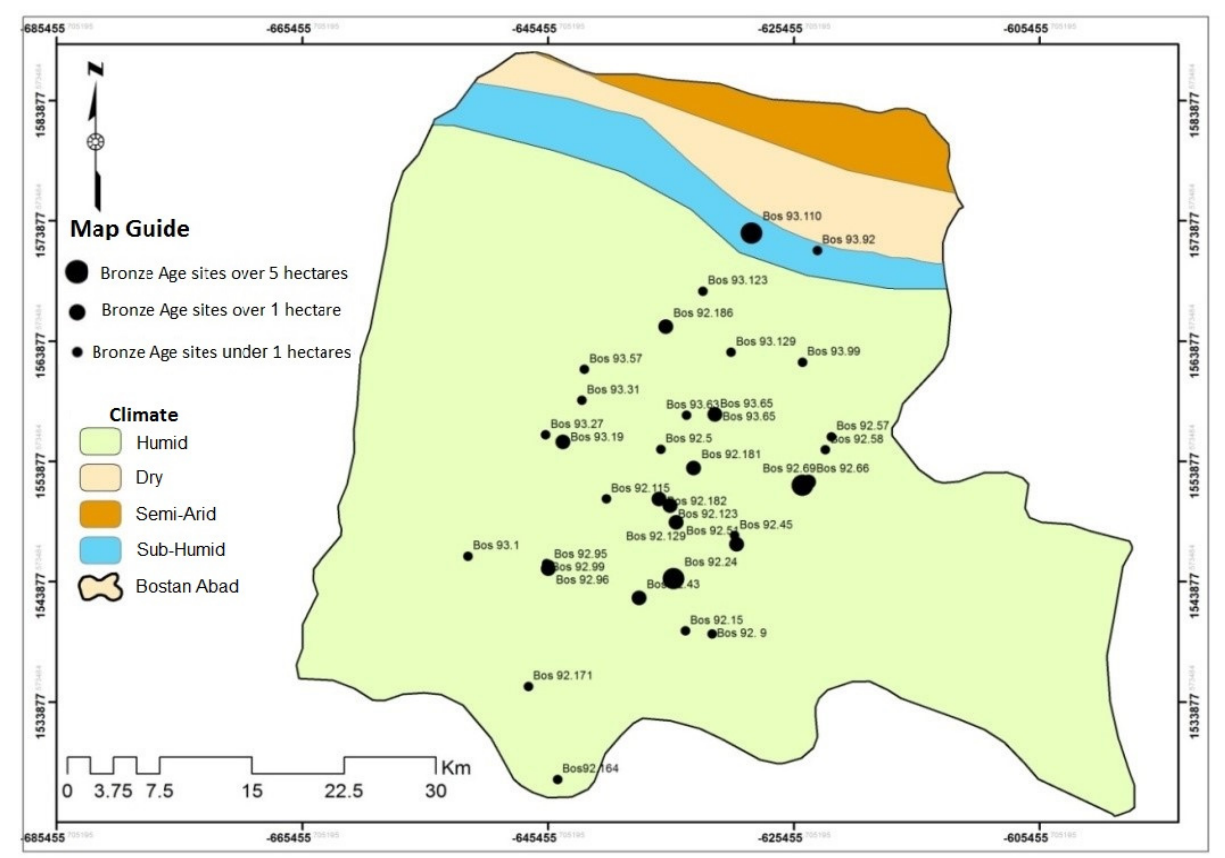

Figure 16. Bronze Age sites of Bostan Abad, according to rate of humidity

\subsection{Distributing Pattern of Bronze Age Sites according to Rate of Slope}

Earths' slope affects landslide, in addition to river flow and transport. Accordingly, five groups appear as: 1) $\left.0-10^{\circ}, 2\right) 11-20^{\circ}$, 3) $\left.21-30^{\circ}, 4\right) 31-40^{\circ}$, and 5) $41-50^{\circ}$. Most of the sites locate at $0-10^{\circ}$ group and include 29 sites, one site at slope $21-30^{\circ}$ that date to Late Bronze Age, and 6 sites locate at 11-20 degrees that all date to Late Bronze Age (Figure17).

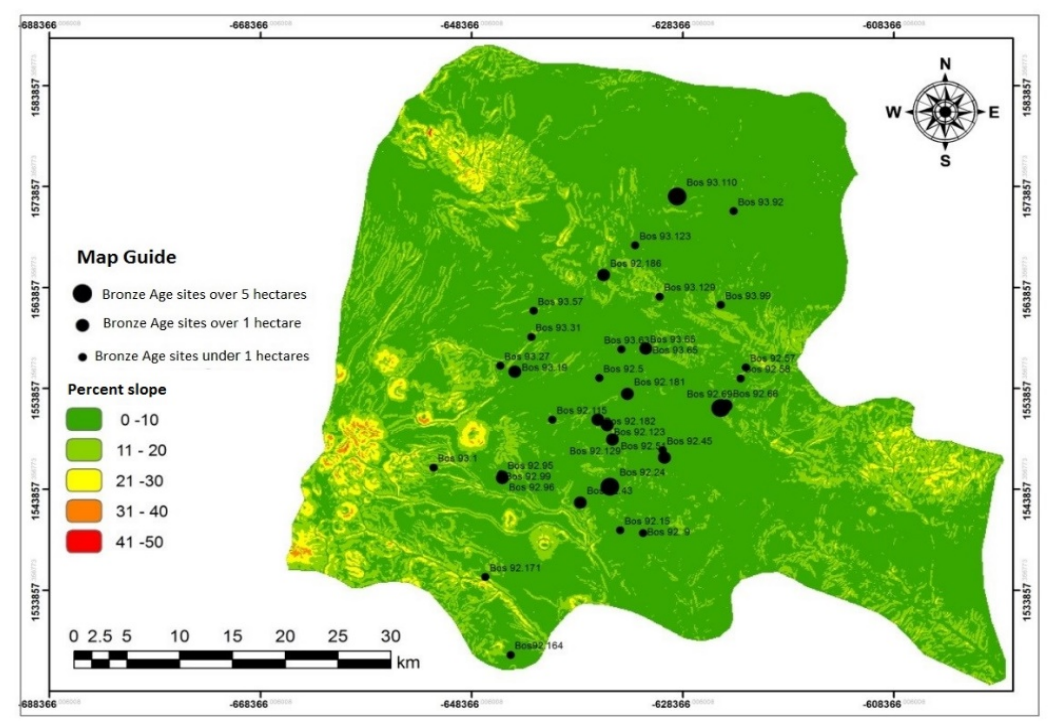

Figure17. Bronze Age sites of BostanAbad, according to rate of slop 


\subsection{Distributing Pattern of Bronze Age Sites according Land Function}

Modern land function indicates regional access to sources. Bostan Abad divide to horticultural lands, dry farming, lands, irrigated farming lands, urban regions, rich meadows, poor meadows, semi rich meadows. 9 sites locate at horticultural lands (among 3 sites that date to Early Bronze Age); 9 sites at irrigated farming lands, among 4 Early Bronze Age sites. Dry farming lands consist of 6 sites among 1 Early Bronze Age site; one site locates at lands of urban centers; while rich meadows have 10 sites, semi rich meadows consist 10 sites, and no sites at poor meadows (Figure 18).

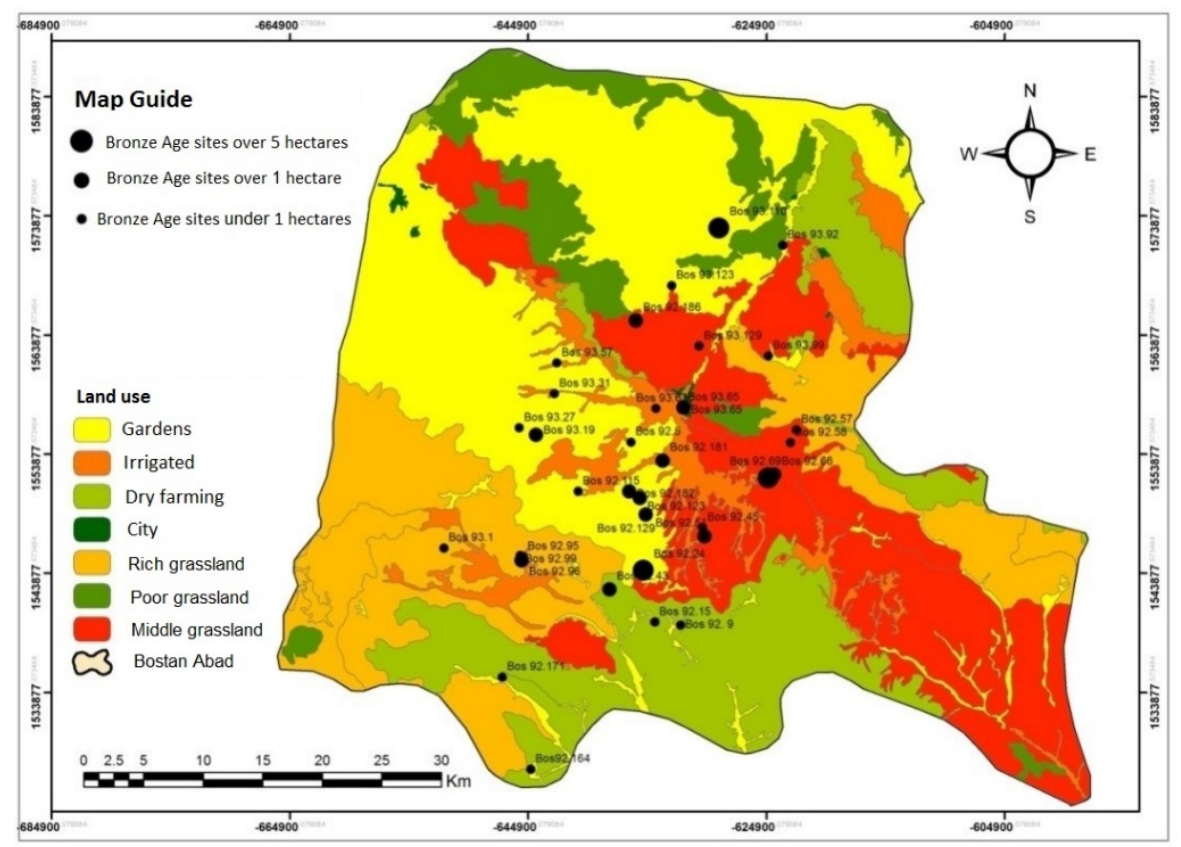

Figure 18. Distribution of sites according land function

Area of sites could play a determinative role in analyzing the same areas, relying on population densities. There were 7 sites lesser than 0.5 hectare at Bronze Age that consisted $21 \%$ of total sites. Second group consists of 12 sites with $0.5-1$ Hectare area, as $37 \%$ of total sites. The third group included 7 sites of $1-2$ hectare that statistically sum up to $21 \%$ of sites. The next group consists of sites with 2-3 hectare area as $6 \%$ of statistics, while two sites categorize in between. As 3\% of statistics, there is only 1 site with 3-4 hectare area, as another group. There were not any sites with 4-5 and 5-6 hectare in area. There was only one site with more than 6-7 hectare area, as $3 \%$ of statistics. There were 2 sites with $7-8$ hectare area, as $6 \%$ of statistics. Finally, sites with more than 8 hectare area that consist of only one site, as 3\% of statistics (Figure 19). 


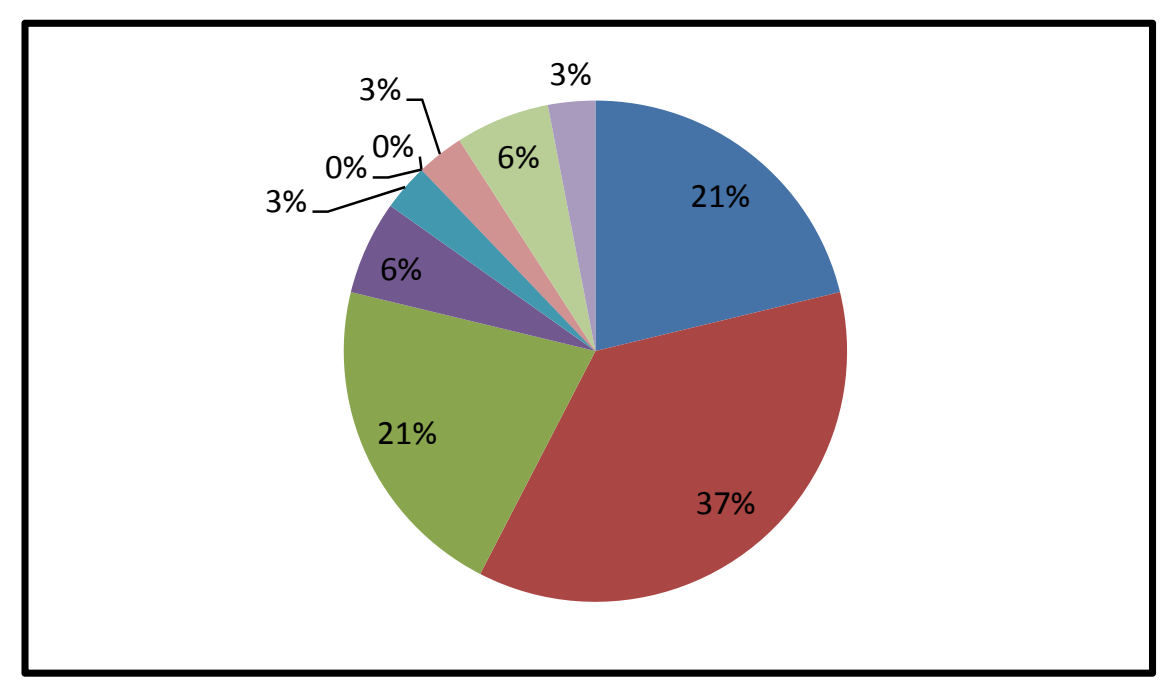

Figure 19. Distribution of sites, considering area

\section{Conclusion}

Bostan Abad region is the most important connective corridor between Central Iranian Plain and Northwestern Iran; however, regional investigations and connective role of the region and expansion of various cultures could reveal significant implications. On the other hand, considering recovered data from regional archaeological systematic survey, presenting holistic view rarely has attracted archaeologists before recent investigations. Regarding interregional and intraregional relations of Bronze Age, investigating the same period imply priorities, considering connective location of Bostan Abad. Conclusions indicate limited numbers of sites dated to Early Bronze Age, whereas, number of residential areas increased during Middle and Late Bronze Age, following collapse of Kura Aras culture. It appears that people commonly settled populated dense centers during Early Bronze Age, while villages emerged during Middle and Late Bronze Age, following collapse of former centers. Because of strategic position of Bostan Abad, typology of potteries of Bronze Age sites indicates intraregional relations of the period. One should notify that there have been reports of Urmia types of potteries as far as central regions of Iran at Sagz Abad, Qazvin Plain. Investigating Urmia type of pottery in the region could be significant in understanding reasons of expansion of the same pottery. Here, there was a presentation of axial role of geographical factor in locating residential areas, using environmental knowledge and Arc GIS software to analyze settlement patterns of Bronze Age at Bostan Abad region. The factors include water resources, altitude, humidity, and land slope; therefore, locating at Sahand foothills, access to flowing waters can be among the main potentials of settling the area. About $47 \%$ of total 36 investigated sites locate closer than $500 \mathrm{~m}$ to rivers; and residents mostly tended to heights of $1700-2000 \mathrm{~m}$ altitude, while around $23 \%$ of sites locate at this altitude. Humidity highly regarded through locating process, because only two sites located at semi-wet area, while the rest 34 sites located within wet areas and no sites could be available at arid and semi-arid areas. Most of the sites, 29 sites, located at slopes of $0-10$ degrees. 


\section{References}

Abedi, A., Omrani, B., \& Eskandari, N. (n.d.). KulTapeh: An early Bronze Age site in north-western Iran. Retrieved from http://www.antiquity.ac.uk/projgall/abedi322/

Ağlar-zade, A. (2009). M.Ö. V-I. Binlerde Yakındoğu—Anadolu—Kafkasya Üçgeninde Kavimler Göçü, Ticari-Kültürel İlişkilerve Etkileşimler. Türk Dünyası İncelemeleri Dergisi, IX(2), 9-18.

Burney, C. A. (1964). The Excavation at Yanik Tepe Azerbaijan (1962). Third Preliminiary Report, 26(1), 54-61.

Badalyan, R. S., Smith, A. T., \& Avetisyan, P. S. (2003). The Emergence of socio political complexity in southern Caucasia (pp. 144-167). In A. T. Smith, \& K. L. A. Rubinson (Eds.), Archaeology in the Borderlands: Investigation in Caucasia and beyond. Cotsen institute of archaeology at UCLA.

Belli, O., \& Bahşaliyev, V. (2001). Nahçıvan Bölgesi'nde Ortave Son Tunç Çağı Boya Bezemeli Çanak Çömlek Kültürü̈. Arkeolojive Sanat Yayınları.

Burney, C. A. (1961). Excavation at YanikTepe, North Western Iran (Vol. 23, No. 2, pp. 138-153).

Burney, C. A. (1962). The excavation at Yanik Tepe, Azerbaijan. Second preliminary report, 24, 134-152.

Edward, M. (1981). The Pottery of Haftvan VIB (URUMIA WARE) (Vol. XIX, pp. 101-140).

Edward, M. (1986). Urmia Ware and its Distribution in North-Western Iran in the second Milllenium B.C. $A$ review of the results of Excavation and Surveys, XXIV, 57-70.

Edwards, M. R. (1983). Excavation in Azerbaijan (north-western Iran). Oxford (BAR international series 182).

Khanali, H. (2014). The report of Arena determination and privacy offer of Qayaliqtepe in Toolesh, khalkhal, Unpublished report. Cultural Heritage, Handicrafts and Tourism Organization of Iran, Tehran.

Kiguradze, T., \& Sagona, A. (2003). On the origins of Kura-Araxes cultural complex. In A. T. Smith, \& K. Rubinson (Eds.), Archaeology in the Borderlands: Investigations in Caucasia and beyond (pp. 95-110). Los Angeles: The Cotsen Institute of Archaeology at UCLA.

Kless, W., \& Krol, S. (1992). Survey in Ost-Azarbaidjan. Rchaeologische Mitteilungenaus Iran. Von Deutschen Archaologischen, Institut Abteilung Teheran, Band. AMI, 25, 1-46.

Kushnareva, K. (1997). The southern Caucasus in Prehistory: Stages of Cultural and socioeconomic Development from the Eight to Second Millennium B. C.

Kushnareva, K. K. (1997). The Southern Caucasus in Prehistory (Stage of Cultural and Socioeconomic Development from the Eighth to the Second Millenium B.C). The University Museum of Pennsylvania, Philadelphia.

Madani, N. A. S. (2015). The study and classification of pottery, Bronze Age, Bostan Abad area according to archaeological survey (M.A. diss.). Islamic Azad University of Abhar.

Meshaninov, I. I. (1925). Doistoricheskiy Azerbaycadjan. I Urartskaya Kultura, Baku.

Mirzaei, S. (2014). M. Ö. II. Binyıl'da Doğu Anadolu'da Boya Bezemeli Seramik Kültürüve Çevre Bölgelerle İlişkileri. In Yayınlanmaış Yüksek Lisans Tezi. Ankara Üniversitesi, Ankara.

Naserisomeyeh, H. (2014). Study and Analysis of the settlement patterns of the Bostan Abad in Chalcolithic period (M.A. diss.). Tehran Univ.

Özfirat, A. (2001). Doğu Anadolu Yayla Kültürleri (M.Ö. II. Binyıl). Arkeolojive Sanat Yayınları.

Özfirat, A. (2011). Erzurum Müzes'inde İnsan Figürlübir Çömlek, Karadeniz'den Firat'a Bilgi Üretimi (pp. 312-318). Önder Bilgi’ye Armağan Yazılar, İstanbul, Bilgin Yayınları.

Rezalou, R., Mohammad, A. S., \& Mehdi, K. (2015). Study of Iron Age Burials Ceramics at Khanghah Gilvan Cemetery in Northwestern Iran. Intl. J. Humanities, 22(1), 131-150.

Sagona, A. (1984). The Caucasian Region in the Bronze Age. BAR, Series 214.

Talae, H. (2006). The bronze age of Iran. Tehran: Samt Press.

Velayati, R. (2006). The archaeological survey report of Bostanabad. First season, in cooperation with the Cultural Heritage. Handicrafts and Tourism Organization of east Azerbaijan and Archeology Institute of Tehran University. 
Velayati, R. (2013). The archaeological survey report of Bostanabad. Second season, in cooperation with the Cultural Heritage. Handicrafts and Tourism Organization of east Azerbaijan and Archeology Institute of Tehran University.

Velayati, R. (2014). The archaeological survey report of Bostanabad. Third season, in cooperation with the Cultural Heritage. Handicrafts and Tourism Organization of east Azerbaijan and Archeology Institute of Tehran University.

Zangiabadi, A., \& Jaber, A. (2011). Analysis of development scale of cities in East Azarbaijan. New approaches in human geography, 4, 69-84.

\section{Copyrights}

Copyright for this article is retained by the author(s), with first publication rights granted to the journal.

This is an open-access article distributed under the terms and conditions of the Creative Commons Attribution license (http://creativecommons.org/licenses/by/4.0/). 